\title{
Toward the integration and advancement of herbal medicine: a focus on traditional Indian medicine
}

This article was published in the following Dove Press journal:

Botanics: Targets and Therapy

13 February 2015

Number of times this article has been viewed

\author{
Saikat Sen \\ Raja Chakraborty \\ Institute of Pharmacy, Assam \\ Down Town University, Guwahati, \\ Assam, India
}

\begin{abstract}
Indian traditional codified medicinal systems and folk medicine are a vast lexicon of herbal formulations and medicinal plants. In last few decades, the popularity of herbal medicine/ products has increased worldwide, not only as part of conventional treatment strategies but also for health care management, and thus the opportunity to promote Indian traditional medicine is increasing globally. Recently people from several developed and developing countries have been attracted toward traditional Indian herbal medicines. A large number of modern medicines are derived from the plants used in Ayurveda and other traditional medicinal systems. Ayurveda and other traditional herbal medicines are capable of addressing some modern unmet medical needs, and can provide the basis for developing potential medicines. Lack of drug standardization, information, quality control, and strict monitoring are the primary lacunae in the promotion of traditional Indian herbal products. In recent years several regulatory and promotional approaches have been undertaken to overcome such problems. Quality control, rigorous research to establish the effectiveness and safety, and credible clinical trials of the herbal products are required. Thus the careful and scientific integration of Indian traditional herbal medicine into evidence-based clinical management of diseases is essential to provide better health care facilities to people.
\end{abstract}

Keywords: traditional medicine, herbal drug, India, Ayurveda

\section{Introduction}

India, a rich chest of biodiversity, has a large diversity of plant species. India consists of $2.4 \%$ of the total geographical area of the world, but accounts for $8 \%$ of global biodiversity, with around 49,000 plant species of which 5,150 species are endemic. ${ }^{1-3}$ The Himalayan range, Western Ghats, North-Eastern Indian hills (Khasi and Mizo hills), and Vindhya and Satpura ranges of the northern peninsula of India are the gold mine of higher plant species. Herbal medicine has special importance in the society, culture, and traditional medicine of India. ${ }^{1}$ Plant-based medicines are at the root of the modern health care system, and are acknowledged for their economic importance also. ${ }^{4}$ Traditional medicinal knowledge and plants play a central role in biological research and drug development. Herbal products or constituents are not only used directly as curative agents, but also as lead molecule in the discovery of new drug. Current research and understanding suggest that the use of crude herbs or herbal products can confer real benefits on health when used long-term. ${ }^{2,5}$

Increasing population and the incidence of side effects of synthetic medicines also accelerate the popularity of alternative medicines. The World Health Organization acknowledged that the goal of "Health For All" cannot be accomplished without
Institute of Pharmacy, Assam Down

Town University, Chandrapur Road,

Panikhaiti, Guwahati, Assam 78I026, India

Tel +9l 96782 I 002 I

Email saikat.pharm@rediffmail.com 
herbal medicines. In a wider context, demand for medicinal plants, herbal medicines, health products, pharmaceuticals, food supplements, cosmetics, etc, is growing in all parts of the world, which indicates the popularity and belief of people in herbal medicines. This in turn has created great scope for India to utilize its traditional knowledge of herbal medicine and repository of medicinal plants in the service of the world population and for the economic growth of India..$^{2,6,7}$

\section{Indian systems of medicine}

Concepts and practices of different traditional medicinal systems in India are about several thousand years old. A large proportion of the Indian population still believes in and receives traditional medical care, which is based on the principles of three ancient codified Indian systems of medicine (ISMs): Ayurveda, Siddha, and Unani. ${ }^{8-10}$ Though different chemicals, minerals, and animal products are used in such system to prepare curative agents, but use of plants have been the basis of treatment in these system. It is estimated that Ayurveda uses 1,200 species of plant, while Siddha and Unani include 900 and 700 species of plant, respectively, in their medicinal preparations. ${ }^{11}$ Ayurveda and other ISMs are judicious combinations of modern science and contemporary clinical medicine, which have the potential to cure a number of diseases in better ways and leverage new leads for modern medicine. ${ }^{12}$ Currently, more that 1.5 million traditional medical practitioners in India are using medicinal plants for preventive, promotional, and curative purposes. ${ }^{13}$

Ayurveda, perhaps the most ancient (6000 BC) of the different organized traditional medicinal systems, is native to the Indian subcontinent and has been practiced since the beginning of the Indian civilization. It can be described as the "science of life", accounting for an integrated observation of the mental, physical, spiritual, and social facets of human beings. ${ }^{14,15}$ Preventive and curative measures are the key components of the Ayurvedic system. Major treatment approaches include the use of "aushadhi" (drugs); "anna" (diet); and "vihara", which includes exercises and a healthy mode of life. ${ }^{14-16}$ The Charak Samhita, Sushrut Samhita, and Samhitas of Vagbhat, together referred to as the Brihattrayee, are considered the three key classics in Ayurveda. Charak Samhita and Sushrut Samhita (100-500 BC) describe over 700 plants, along with their detailed classification, pharmacological, and therapeutic characteristics. ${ }^{12,17}$

In the pre-Vedic period (approx. 3000 BC-2000 BC), the Siddha system of medicine originated in the southern part of India, 18 "siddhas" (ancient practitioners of Siddha medicine) are believed to have developed this system which are written in Tamil and mainly practiced in Tamil Nadu. ${ }^{14,18}$ The Siddha medicinal system recognizes three humoural concepts: "vata" (wind), "pitta" (bile), and "kapha" (phlegm). Examination of the pulse, urine, and different anatomical features like the tongue, voice, complexion, eyes, touch (to find dry, warm, cold, sweating condition), and stools are commonly used as diagnostic criteria in Siddha medicine. ${ }^{16,18,19}$

The basics of the Unani system of medicine were laid by Hippocrates and later by Galen. In the eleventh century, the Unani system was introduced in India by Arabs and Persians. The fundamental theory of the Unani system is "humoral theory", which presupposes the presence of four humors blood, phlegm, yellow bile, and black bile - in the body, and for Unani practitioners diagnosis mainly depends on pulse reading, and examination of the urine and stools. ${ }^{20,21}$ The main therapeutic approaches in this system include dietotherapy, or "Ilaj-bi-ghiza" (use of specific diet); regimental therapy, or "Ilaj-bil-tadbeer" (exercise, change of climate, massage, venesection, leaching, cupping); pharmacotherapy, or "Ilaj-bi-dawa" (use of medicines from herbal, mineral, and animal sources); and surgery, or "Ilaj-Bil-Yad". ${ }^{20-22}$

Folk medicine (also known as "tribal" or "indigenous" medicine) also plays an important role in Indian society, mostly in rural/indigenous/ethnic communities. This type of knowledge is usually passed verbally from ancestors of the particular group of people without any written script. It has been estimated that more than 8,000 species of plants are used by the tribal and ethnic communities in India as part of their health care systems. ${ }^{7,23}$ Approximately 25,000 effective plant-based formulations are used in folk medicine and are commonly used by rural and ethnic communities in India. ${ }^{13}$

\section{Herbal medicine and modernity: can Indian traditional medicinal systems show the way forward? Importance of herbal medicine}

Herbal medicines are truly in a league of their own, and have stood the test of time until now. But unfortunately the utilization of herbal medicine for the management of diseases is less despite of its potential. A large number of ethnic and rural people use and stoically play a crucial role in protecting the ancient medicinal knowledge related to plants from fading away into oblivion. Herbal medicine is due a revival. However, incorporating herbal medicine into the true mainstream of modern health care and ensuring modern safety and efficacy standards is not an easy task.

In India, about $65 \%$ of the population mainly uses traditional medicine for their health care needs. Inequities in the 


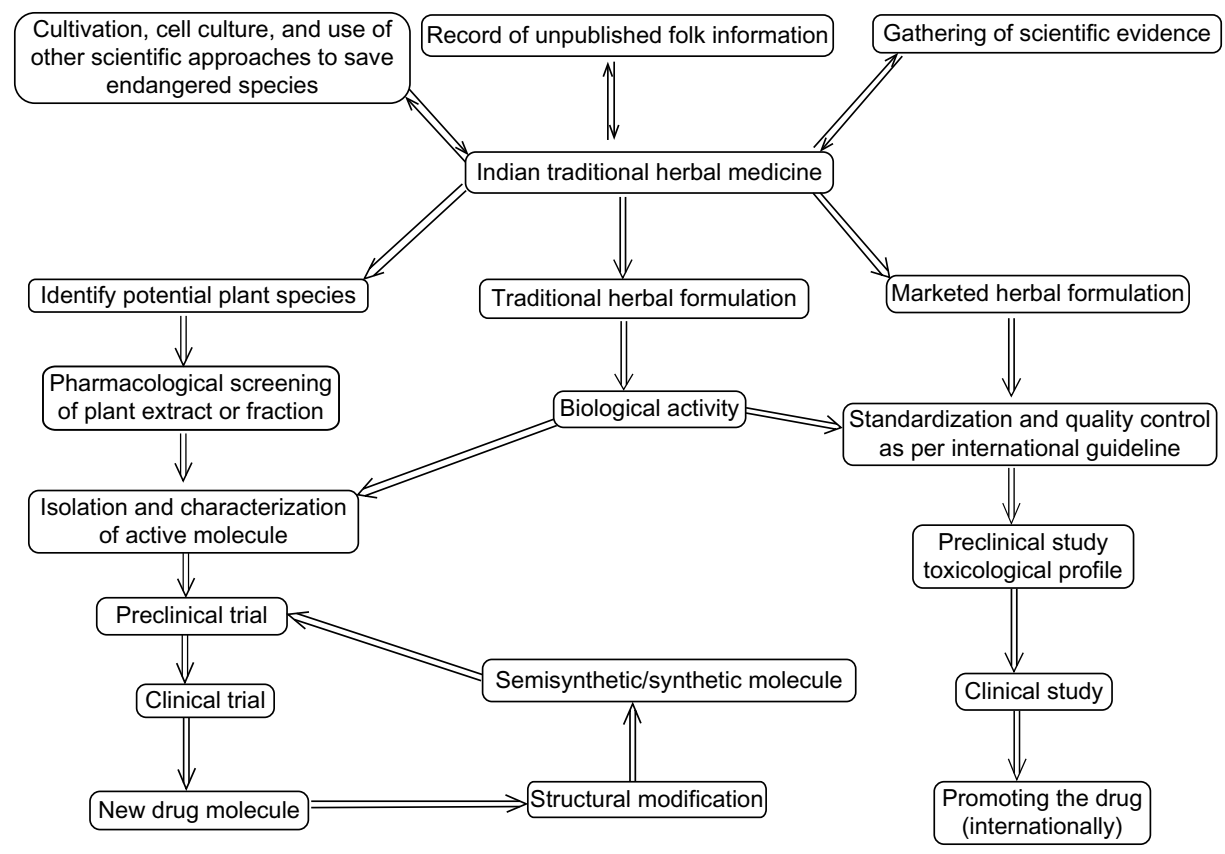

Figure I Strategy for advancement and integration of traditional herbal medicine into modern medicine.

accessibility, availability, and affordability of modern health care make herbal drugs more popular in rural and remote areas. ${ }^{24,25}$ Demand for traditional medicine in developed countries is also increasing. About 40\%-50\% people in Germany, $42 \%$ in the USA, $48 \%$ in Australia, and $49 \%$ in France are using traditional medicine. In the twenty-first century, herbal drugs and products from plant sources are increasingly being acknowledged in developed countries and also among the people who can afford costlier allopathic medicines, with the hope of a more eco-friendly, bio-friendly, and relatively safer treatment strategy.,24,25 Among the 49,000 plants of the Indian subcontinent, about $20 \%$ are global species. It was estimated that more than 3,500 higher and lower plant species have medicinal value, although only 500 species of medicinal plants are used by the Ayurvedic industry. ${ }^{1,2}$ Several reports have suggested that almost $80 \%$ of drug molecules are of natural origin or inspired by natural origin. It has been estimated that almost 50\% of drugs approved since 1994 are based on natural products. ${ }^{26}$ Undoubtedly, a lot of plants contain substances of medicinal value which have yet to be discovered. Indian traditional medicinal systems believe in a holistic approach, and are considered as ancient forms of system-biology-based medicine. Diagnosis and treatment strategies provide more individualized methods. ISMs have a very complex and logical approach to diagnosis, which are based on rational observation, and use a number of potent herbal preparations, thus have become an important target of medical research.
A key area for the popularity of herbal products is nutritional supplements. Herbal supplements afford nutrients that are lacked or not consumed in an adequate quantity through the diet. Herbal supplements may contain vitamins, minerals, macronutrients, and antioxidants, etc, which are essential for good health. Thus, the demand of several Indian formulations - like chyawanprash, musli pak, and ashwagandhadi lehyam - is increasing. ${ }^{27}$ Figure 1 shows the strategy for advancement and integration of traditional herbal medicine into modern medicine.

\section{Present scenario and future}

Review of different national pharmacopeia revels that at least 120 distinct chemical products/moieties from herbal sources have been utilized as lifesaving drugs. It is predicted that among the estimated 250,000-400,000 plant species of world only $6 \%$ have been screened systematically for their biological activity and 15\% have been investigated phytochemically. ${ }^{28}$ It is predictable that natural compounds and their derivatives comprise nearly $60 \%$ of all drugs in clinical use and medicinal plants contribute not less than $25 \%$. Between 1981 to 2002, around 119 drugs were approved and of those around $60 \%$ of anticancer and $75 \%$ anti-infective drugs could be related to natural substances. ${ }^{29}$ Thirteen natural products were approved as drugs between 2005 and 2007. Currently, more than 100 natural products (drugs) are in clinical trials and about 100 molecules or compounds are in the preclinical phase of drug discovery. ${ }^{30}$ Several 
bioactive molecules from plants, especially from those used in Ayurveda, have been discovered, such as reserpine for high blood pressure, psoralens for vitiligo, alkaloids from Holarrhena antidysenterica (L.) against amebiasis, Mucuna pruriens for Parkinson's disease, piperidines asbioavailability enhancers, vasicine and vasicinone as bronchodilators, hydroxycitric acid for obesity, bacosides to treat mental retention, picrosides as hepatoprotective agents, phyllanthins for viral infections, and withanolides and steroidal lactones as immunomodulators. Current scientific knowledge, better clinical observation, and superior thoughtful consideration help to explore Indian traditional medicine in an advanced way and utilize old molecules for new therapeutic applications. For instance, forskolin is currently acknowledged as a potent adenylate cyclase activator and antimicrobial berberine alkaloids are used to cure dyslipidemia. ${ }^{26,31}$ A typical, systematic research on plants to find new bioactive molecules is expensive and inefficient. The high cost of and the time taken for this process are the main hurdles. One of the most important approaches in the discovery of a new drug would be recourse to the information accessible in traditional Indian medicinal systems, which are based on the proven therapeutic utility of the medicinal plants of India. ${ }^{12}$

Indian herbal medicine makes numerous medical claims for the treatment of many acute and chronic diseases and symptoms, the prevention of disease, and the improvement of quality of life. Herbal medicines also contain different chemical constituents that could act singly or synergistically. The advancement and success of Indian traditional medicine, especially Ayurveda, around the world is mainly due to its being a holistic approach to treatment. ${ }^{32}$ Ayurveda, a wellwritten medical text, describes scientific view on diseases and treatment that makes it unique. Currently, Ayurveda is included in the Indian national health care system. Several countries, like the UK, the United Arab Emirates, Sweden, Indonesia, and the USA have acknowledged the Ayurvedic health care system and more than 30 countries are on the verge of doing the same..$^{33}$ It has been estimated that almost two-thirds of people in the USA use one or more alternative treatment strategies, of which most are drugs from herbal sources. The demand for dietary supplements and traditional medicines is high in the US and thus more than 1,500 herbals are sold for such proposes. ${ }^{31}$ A survey in 2007 revealed that more than 200,000 American adults have used Ayurvedic medicine. ${ }^{34}$ Ayurveda is gaining momentum as a successful alternative to the conventional medicinal system through its systematic strategy of curing and preventing diseases using natural resources. ${ }^{35}$ Increased use and misuse of current allo- pathic medicines provides enthusiasm for integrating alternative medicine and conventional medicine. ${ }^{36}$ Ayurvedic herbal medicine confers benefits to $75 \%$ of the sub-continental population of 1,000 million and millions of others around the world.$^{37}$ Herbal therapies or plants used in ISMs have the potential to become the drugs of the future. Indian herbal medicine could meet some modern unmet medical needs, provide basic health care needs, and can offer the basis for developing potential medicines. Increase in the demand and utilization of herbal products provides fertile ground for the revival of Indian herbal medicine. ${ }^{34}$

\section{Revival of Indian traditional herbal medicine: current situation and impediments Role of Indian organizations}

Phytochemicals from ISMs, particularly from Ayurveda, are beginning to attract interest across the world and huge efforts have been initiated to include traditional herbal medicine in modern medicine. India has enormous facilities for research; the Central Drug Research Institute (CDRI), Council of Scientific and Industrial Research (CSIR), Central Institute of Medicinal and Aromatic Plants, National Botanical Research Institute, Regional Research Laboratories, and National Chemical Laboratory are playing vital roles in this regard. Several government and nongovernmental organizations from different countries have actively started researching on plants and formulations described in Ayurveda. ${ }^{28}$

\section{Indian traditional medicinal plants in preclinical and clinical trial}

Global acceptance of Ayurveda is increasing and demand for medicinal plants from India is in upsurge. ${ }^{35}$ In recent years, a number of drugs from ISMs have undergone clinical trials to verify their efficacy. Products from Ayurveda have been successfully evaluated in clinical trials for the treatment of bronchial asthma, rheumatoid arthritis, ischemic heart disease, and cancer, among other illnesses. ${ }^{28,38-41}$ Indian medicinal herbs (eg, ashwagandha, guggulu, haridra, kutki, shatavari, atmaupta, amruta, brahmi, guduchi, amla, and ginger) and complex herbal formulations (rasagenthi lehyam, brahma rasayana, semecarpus lehyam, triphala, and other rasayanas) were evaluated through preclinical studies and reported to possess positive effect. ${ }^{33,42,43}$ The US National Center for Complementary and Alternative Medicine has funded several research works based on Ayurvedic medicinefor example, on the use of curcuminoids in cardiovascular 
diseases, a compound from $M$. pruriens (L.) used against the side effects of anti-Parkinson's drugs, the use of three plants (ginger, turmeric, and Boswellia) to cure arthritis and asthma, and to validate the effect of Centella asiatica (L.) against Alzheimer's disease. ${ }^{34}$ Potent vaccine adjuvant activities of Withania somnifera (L.) and Asparagus racemosus wild have been evaluated in experimental systems, which suggests their importance in immunobiological preparations.

Controlled clinical trials are essential to establish the effects of drug and to compare the potency of traditional medicines with allopathic medicines. Clinical trials on Indian traditional medicines are encouraging but warrant many more. For instance, "piperine", a bio-enhancer from pipali, has been successfully evaluated in clinical studies; a multicenter study found that a Vijayasar (aqueous decoction of Pterocarpus marsupium Roxb) was effective as a hypoglycemic and antidiabetic drug; Lupin Ltd (Mumbai, India) filed an Investigational New Drug (IND) application; a US patent has been approved for the development of a herbal anti-psoriatic medicine containing Argemone mexicana (L.); the CDRI developed a product containing fraction of gugulipid from Commiphora wightii for the treatment of hyperlipidemia and atherosclerosis. Boswellia serrata Roxb. gum resin has been commercialized by Regional Research Laboratories (Jammu) as a nonsteroidal anti-inflammatory drug, which also demonstrates hypolipidemic effect. ${ }^{28,44-47}$ A double-blinded clinical trial has been carried out with "arogyawardhini" (an Ayurvedic product containing amla, bahera, harar, guggulu, kutki, neem, chitrak mool) in viral hepatitis, while effects of $M$. pruriens, Phyllanthus amarus, and Tinospora cordifolia have been investigated in the treatment of Parkinson's disease, hepatitis, and obstructive jaundice, respectively. ${ }^{48}$ The CSIR and CDRI have developed a bacoside-enriched standardized extract of plant brahmi (Bacopa monnieri L.) used to enhance memory and learning; the product is already marketed in Asian and European countries under different brand names. Brahmi is described in the Charak Samhita and Sushruta Samhita, and has been used as a brain tonic for 3,000 years. ${ }^{49}$

\section{Traditional medicinal formulations containing plants}

A clinical trial of a well-known classical Ayurvedic formulation, "triphala", which is prepared by combining the fruits (without seeds) of Terminalia chebula Retz., Terminalia bellerica Roxb., and Emblica officinalis Gaertn., showed potent effects against constipation and other gastric problems. ${ }^{50}$

A standardized formulation prepared with purified extract of ashwagandha ( $W$. somnifera), guggulu ( $B$. serrata), and haldi (Curcuma longa) was effective in improving a jointswelling condition and has a good safely profile when given to people suffering from rheumatoid arthritis. ${ }^{39}$

Another classical example of herbal formulation is 'prostalyn', which contain two traditional Indian medicinal plants (Murraya koeniggi and Tribulus terrestris) and used to treat benign prostate hyperplasia.

A short-term clinical trial demonstrated that "tarika", an Ayurvedic pimple remover herbal powder (containing T. chebula fruit, T. bellerica fruit, Santalum album heartwood powder, Curcuma aromatica rhizome, Embelia ribes fruit, Berberis aristata dried stem, Acorus calamus rhizome, Embelia officinalis fruit, Taxus baccata leaf, Myristica officinalis fruit endosperm, and Cyperus rotundus rhizome) has good effect in patients suffering from moderate to severe degrees of acne vulgaris. ${ }^{52}$

"Guduchyadi ghrita medhya rasayana", an Ayurvedic formulation containing several Indian medicinal plants like guduchi, apamarga, vidanga, shankhapushpi, vacha, haritaki, kushtha, and shatavari has showed promising effects in clinical trials by improving the mental health, memory, stress, and depression conditions, which might be helpful in slowing down the aging process. ${ }^{53}$

"Amalki rasayana", an Ayurvedic herbal product, has showed promising effects in patients suffering from agerelated macular degeneration. ${ }^{54}$

A number of traditional plant-based formulations have been developed by the CSIR. Some of these are $\alpha, \beta$ arteether (E-mal - which was included in India's National Malaria Control Programme) and elubaquine (Aablaquin) as antimalarial drugs; Asmon ${ }^{\circledR}$ to cure asthma; Sallaki ${ }^{\circledR}$ of B. serrata to treat rheumatoid arthritis and osteoarthritis; Livzon poly-herbal formulation, which has been evaluated as a hepatoprotective agent; and immines, a multi-herbal drug to cure immunemodulatory activity. ${ }^{55}$

A number of Siddha herbal formulations like Gly Cyn Neu ointment against diabetic neuropathic symptoms, combination of amukkara choornam and linga chenduram, and two other poly-herbal (for internal and external use) formulations against rheumatoid arthritis have also undergone successful clinical trials. ${ }^{56-58}$

Since the Vedic period, ISMs have been enriched with a number of herbal drugs to cure jaundice and viral hepatitis. It has been estimated that more than 6,000 commercial herbal medicines are used worldwide for the management of liver disorders, and among them nearly $40 \%$ patents are for poly-herbal formulations (including silymarin from Silybum marianum L. Gaertn. seed, Picrorhiza kurroa Royle ex Benth extract, and 
extracts of plants of different Phyllanthus sp. and glycyrrhizin preparation) consisting of different combinations of 93 Indian herbs, which are existing in the Indian market. ${ }^{48}$

Several patented and proprietary herbal medicines, like Arishtas, Churnas, Rasayanas, Ghrits, and Ras, have been marketed in the form of modern medicines such as tablets, capsules, powders, syrups, ointments, or even as gels. According to a survey, more than $70 \%$ of all drugs sold as Ayurvedic medicine in the Indian market are branded editions - patented and proprietary medicines. ${ }^{12}$

The Traditional Knowledge Digital Library (TKDL) is a unique approach by the Government of India to compile and preserve traditional medicinal knowledge and is in the public domain.

Currently, a number of botanicals are undergoing clinical trial using reverse pharmacology processes to find new drugs to cure/prevent hepatotoxicity, viral hepatitis, cancer, diabetes, and arthritis based on the traditional knowledge of India. ${ }^{12}$ Herbal medicines and medicinal plants described in ISMs, including folk medicine, have emerged as a great source of new drugs.

\section{Potent phytochemicals from Indian medicinal plants}

Turmeric (C. longa) is a classical Indian medicinal herb recognized for its great clinical utility by ISMs. It is used in the treatment of pain, wounds, and sprains, as well as skin, pulmonary, gastrointestianl tract (GIT), and liver disorders. "Curcumin", the bioactive component of turmeric, has emerged as a potential therapeutic molecule against Alzheimer's disease, different malignant diseases, diabetes, allergies, and arthritis, among other disorders. ${ }^{59,60}$ Rauwolfia serpentina L. (sarpagandha), an ancient medicinal plant of India, is used to treat hypertension, mental disturbance, insomnia, gastrointestinal disorders, epilepsy, anxiety, and schizophrenia. The plant is also used to cure several hypertension-related problems like headache, dizziness, amenorrhea, oligomenorrhea, and dysmenorrhea in Siddha medicine. ${ }^{61,62}$

In the beginning of $1930, R$. serpentina was investigated for its tranquilizing and sedative effects. In 1949, Indian cardiologist Rustom Jal Vakil reported a hypotensive effect of its root extracts, which attracted the interest of researchers. The alkaloids ajmaline (an antiarrhythmic agent) and reserpine were isolated from sarpagandha root in 1931 and 1952, respectively. ${ }^{63}$ The discovery of reserpine was a breakthrough for the treatment of hypertension and psychotic disorders, though this drug is seldom used now. ${ }^{48}$
B. monnieri is a potent medicinal herb of Ayurveda used to cure epilepsy, asthma, ulcers, tumors, and inflammation, among other things. Subsequent investigations led to the discovery of bacosides..$^{51,64}$

A labdane diterpene, "forskolin" was isolated from the root of Indian medicinal herb Coleus forskohlii (makandi). Forskolin has a potent and direct adenylate cyclase activating property and could be a potent molecule to treat congestive cardiomyopathy, glaucoma, and asthma. Clinical studies of forskolin to manage obesity and weight are ongoing. A number of semi-synthetic derivatives of forskolin have been developed and have been approved for several clinical studies. ${ }^{65,66}$

"Flavopiridol" and "P-276-00" are the novel semisynthetic derivatives of an alkaloid (rohitukine) isolated from Amoora rohituka (Roxb.) Wight and Arn. and Dysoxylum binectariferum (Hook.f.), and are in advanced stages of clinical trials as anticancer drugs. ${ }^{67,68}$ The anti-inflammatory, anticancer, anti-fertility, anti-implantation, and immunomodulatory activities of rohitukine have also been investigated. "Dysobinin", a compound from D. binectariferum fruits, has exhibited potent central-nervous-system depressant and mild anti-inflammatory effects. ${ }^{69}$ Both the plants (A. rohituka and $D$. binectariferum) have been used by physicians of ISMs for a number of disorders related to the liver and spleen enlargement and inflammation. ${ }^{69,70}$

"Diosgenin" is a major bioactive steroidal sapogenin isolated from several traditional medicinal plants including Trigonella foenum-graecum L. and Dioscorea spp. These plants are commonly used in Ayurvedic and Siddha formulations. Dioscorea bulbifera L. (varahi) is used to treat dysuria, urinary calculus, urine disorders, calculus, disorders of vital point, and trauma, while T. foenum-graecum (methi) is used against pain, facial palsy, abdominal problems, hernia, and neurological disorders. ${ }^{71,72}$ Catharanthus roseus L. (nityakalyani) has a long history in ISMs as a diuretic, antidysenteric, hemorrhagic, and antidiabetic drug.

Two alkaloids, vinblastine and vincristine, have been isolated from Catharanthus roseus leaves and recognized as anticancer agents for variety of cancers such as lymphocytic lymphoma, Hodgkin's disease, testicular carcinoma, and choriocarcinoma. Vincristine is used in acute leukemia, lymphosarcoma, and Wilms' tumor. ${ }^{73}$

Guggulsterone was discovered from the gum resin (guggulu) of Commiphora mukul. Guggulu is an important constituent of Ayurvedic medicine used to cure several disorders like obesity, bone fractures, arthritis, inflammation, and cardiovascular disease. ${ }^{74}$ The CDRI has successfully completed 
clinical trials of gugulipid as a lipid-lowering agent, and marketed it in the form of tablets and granules. ${ }^{50}$

"Darakchasava", an ancient Indian herbal preparation containing grape (Vitis vinifera L.) extracts, is used as a cardio tonic and for the treatment of other disorders. Analysis of darakchasava indicated the presence of resveratrol and pterostilbene. Resveratrol was isolated in 1940 from Veratrum grandiflorum, and is also found in grapes, berries, and peanuts. Resveratrol has been found to possess cardioprotective and anticancer effects. ${ }^{74}$

W. somnifera L., a medicinal plant described in Ayurveda, is known to process anti-inflammatory, cardio-active, and central nervous system activities. Withanolides, which is extracted from W. somnifera and used in Ayurvedic medicine to cure arthritis and menstrual disorders, has been found to be an inhibitor of angiogenesis, inflammation, tumor development, and oxidative stress, as well as a promoter of cardioprotection. ${ }^{74}$

The gum resin of salai guggul ( $B$. serrata) is used in Ayurveda to cure rheumatic diseases and respiratory and liver disorders. Several researchers have discovered the active biomolecule of this resin to be boswellic acid. Boswellic acid and its derivatives have emerged as future anticancer agents. ${ }^{74,75}$

The chemical investigation of a few Ayurvedic antiarthritic drugs has led to the discovery of synthetic antiinflammatory drug molecules like phenylbutazone, indomethacin, and corticosteroids. ${ }^{28}$

Indian medicinal plants have been found to be a source of many different modern bioactive agents; for example, quinine from Cinchona spp., pilocarpine from Pilocarpus jaborandi, atropine from Atropa belladonna L., cocaine from Erythroxylum coca Lam., morphine and codeine from Papaver somniferum L., cardiac glycosides from Digitalis spp., artemisinin from Artemisia annua L., paclitaxel from Taxus baccata L. and Taxus brevifolia L., berberine from Berberis spp., pristimerin from Celastrus paniculata Willd., quassinoids from Ailanthus spp., plumbagin from Plumbago indica L., allicin from Allium sativum L., emetine from Cephaelis ipecacuanha (Brot.) L.Andersson, glycyrrhizin from Glycyrrhiza glabra L., nimbidin from Azadirachta indica A. Juss., catechin from Acacia catechu Willd., sophoradin from Sophora subprostrata, thevenerin and neriifolin from Thevetia spp., podophyllin from Podophyllum emodi, homoharringtonine from Cephalotaxus, camptothecin from Camptotheca acuminata. ${ }^{73}$

\section{Challenges}

The National Medicinal Plants Board, India, estimated about $77 \%$ of the medicinal plants used in the country for several traditional medicinal formulations are from forests and wastelands. The International Union for Conservation of Nature Species Survival Commission estimated that there are 19 extinct, 43 extinct/endangered, 149 endangered, 108 vulnerable, and 256 rare plant species in India. ${ }^{4}$ Thus reducing overexploitation, stopping deforestation, cultivating medicinal plant, and using cell cultures and other scientific methods are required to protect the medicinal plants.

Further, the incidence of biopiracy is a major impediment to the advancement of Indian herbal medicine. A survey by a TKDL task force based on 4,896 references revealed that 90 medicinal plants were listed in the US Patent and Trademark Office database, and about $80 \%$ of references were related to seven medicinal plants (kumari, mustaka, tamraparna, garjara, atasi, jambira, and kharbuja) of Indian origin. The task force also revealed that 360 of 762 patents were based on medicinal plants that could be classified as "traditional". ${ }^{76}$ This indicates the potential of Indian traditional knowledge and herbal drugs to address a large number of ailments in the future.

The primary lacunae with Ayurvedic and other traditional herbal products are the lack of drug standardization, information, quality control, and strict monitoring. ${ }^{73}$ About 13 Asian herbal products have been found to contain a number of contaminants. A study has found that among 260 Asian patented medicines, about $25 \%$ contained heavy metals beyond the limit, while undeclared drugs to increase therapeutic efficacy were found in $7 \%$ of those medicines. A large number of Ayurvedic formulations are available in spurious, adulterated, or misbranded forms, and several preparations do not follow the traditional proper rules or texts on how to prepare such formulations. ${ }^{28,77}$ A report on Ayurvedic medicine has found that about $20 \%$ of such medicines purchased through the Internet contained high levels of lead, mercury, and arsenic. Recently, the US Food and Drug Administration found that several herbal supplements contained currently available drugs like lovastatin (eg, Mevacor ${ }^{\circledR}$ ), sildenafil (eg, Viagra $\left.^{\circledR}\right)$, estrogen, alprazolam (eg, Xanax $\left.{ }^{\circledR}\right)$, indomethacin $\left(\mathrm{eg}, \operatorname{Indocin}^{\circledR}\right)$, and warfarin $\left(\mathrm{eg}, \mathrm{Coumadin}^{\circledR}\right)$ as adulterants. ${ }^{34,78}$ Herbal manufacturers from India usually follow World Health Organization guidelines for quality control, but the adulteration of formulations remains a major concern for both the domestic and export markets of Indian herbal products. $^{28,77}$

The majority of Ayurvedic formulations contain crude extracts in mixtures of different ingredients. Some studies have showed that the active principles of such products fail to 
produce the desired effects when isolated individually. This may due to the synergistic activity of several components present in a formulation. In the absence of pharmacopeial data on such herbal formulations, it is difficult to isolate or standardize the active components. Currently, the Ayurvedic Pharmacopeia has been compiled on modern lines and is updated often as per requirement. ${ }^{73}$

Quality control and drug-herb interaction are other drawbacks. Several herbal products can interact with food, allopathic drugs, or pharmaceuticals, but unfortunately, for the majority of products, such information is lacking. In general, after 1 year of collection, herbs lose their medicinal value; powders prepared from such herbs remain effective for nearly 6 months, while pastes or ointments are effective for 1 year. ${ }^{77}$ Several herbs may be responsible for serious adverse effects - for example, creosote bush causes hepatotoxicity, ephedra may be responsible for cardiovascular complications and hepatotoxicity, and kava may induce hepatotoxicity. Several manufacturers do not follow the appropriate methods of preparation and do not use the proper parts of the plant, which may be responsible for toxicity - as in the case of kava-induced toxicity. ${ }^{79}$ This situation needs to be addressed properly for the growth of Indian herbal medicine.

In the last 30 years ISMs, especially Ayurveda, have became remarkably popular in European countries; it has been estimated that over 5 million European people have used such traditional medicine in the last few decades. Due to the popularity of traditional medicine, thousands of under-/ nonqualified traditional medicinal practitioners/institutions have emerged in Europe, which has led to a serious situation. ${ }^{37}$ In the last decade, the European Union demanded bibliographic evidence and preclinical safety data before the marketing of traditional medicinal products. Thus, proper standardization of and research and data on products' quantitative and qualitative particulars of constituents, methods of manufacturing, therapeutic uses, contraindications, toxicity profiles, posology, forms, and routes of administration are essential for the promotion of Indian traditional medicine in Europe.$^{80}$ In Europe, due to some legal problems, the future of Ayurvedic medicine is in the dark, and this requires urgent attention. ${ }^{81}$ A recent survey has concluded that Ayurveda has the potential to satisfy the needs of therapists and patients, despite worldview differences in Europe ${ }^{82}$

\section{Herbal medicine and Indian economy}

Markets for medicinal plants and herbal medicine are lucrative and important for economic growth of India. Several pharmacopeia have included a number of important herb and herbal products. For instance, the Ayurvedic Pharmacopoeia of India included monographs for 258 Ayurvedic drugs, the Indian Pharmacopoeia 2010 incorporated 89 monographs for herb and herbal products, while the Indian Herbal Pharmacopoeia 2002, published by the Indian Drug Manufacturers Association, included 52 monographs on widely used medicinal plants of India. ${ }^{4,28}$ Domestic trade of the Ayurveda, yoga and naturopathy, Unani, Siddha, and homeopathy (AYUSH) industry is about INR80-90 billion. Export of medicinal plants and their products from India is about INR10 billion. In 2010, the production of herbal drugs in India was about INR4,000 crores, with 1,650 herbal formulations. ${ }^{4}$ Trade of herbal products is now US $\$ 120$ billion and is expected to reach to US $\$ 7$ trillion by $2050 .{ }^{83}$

In spite of the vast potential, the Indian share of this trade is at present quite low. About 500 plant species are used in Chinese medicine, whereas more than 7,000 species are used in ISMs. The People's Republic of China's global share of medicinal plant exports is about $28 \%$, while India's share is only $8.13 \%$. India ranked second in medicinal plant exports after the People's Republic of China in 2009. ${ }^{4}$ A report from the Associated Chambers of Commerce and Industry of India estimated that the value of the herbal industry was about INR7,500 crores in 2010 and that its value would reach INR15,000 crores by $2015 .{ }^{85}$ India's share in export of AYUSH products increased by $10.4 \%$ over $2012-2013$ compared with in the previous year. Globally, the demand for Indian herbs and herbal medicines is increasing. Growth of about $11 \%$ in the export of herbs and herbal medicines to the European Union was noted in 2012-2013 compared with in the previous year. ${ }^{83}$

It has been estimated that about 880 medicinal plants are involved in Indian trade. Of these, 42 species are imported and 48 species are exported. ${ }^{85}$ European countries hold the greatest share of the total herbal market (45\%), followed by Association of Southeast Asian Nations countries (19\%), Japan (16\%), and North America (11\%). ${ }^{86}$

Some of the important medicinal plants/products of India are E. officinalis Gaertn., isabgol (psyllium husk), the leaves and pods of senna, the leaves and powder of henna, myrobalans, jojoba seed, gymnema powder, and garcenia., ${ }^{4,86}$ Traditional Indian medicinal knowledge and the diversity of plants in India are well recognized, thus urgent attention is required to cherish this knowledge nationally and internationally.

\section{Future aspects and India's position}

Currently, the paradigm of medicine has shifted from not only curing clinical diseases but also maintaining good 
health. Today, medicines are available not only for treating illnesses but also for enhancing quality of life and health more broadly. ${ }^{87}$ Thus, the integration of traditional herbal medicine into the modern health care system is the need of the time. The inclusion of traditional herbal medicine in modern health care offers a large benefit to society: it tenders reciprocal advantages to each system, improves the knowledge of general health care, increases the number and quality of practitioners, endorses the dissemination of primary health care knowledge, and is also helpful in providing basic health care to people in all parts of society. ${ }^{78}$ However, several fundamental problems - like basic differences between different medicinal systems, differences in the concept of spiritualism, fear of the harmful effects of traditional preparations, and decline in the quality due to lack of regulation and standardization - are associated with this. ${ }^{88}$

The increasing use of herbal traditional therapies like Ayurveda insists on more systematic and sound scientific evidence for therapies and the effectiveness of medicines. ${ }^{28}$ The promotion and globalization of Indian traditional herbal medicine requires a more realistic and strong approach to overcome the difficulties. The People's Republic of China has effectively modernized its approaches by introducing government-sponsored good agricultural policies and good manufacturing practices for traditional medicine. Similar integrated strategies are essential for the growth of Ayurveda, Siddha, and Unani medicines globally. The Government of India has started several drug-testing laboratories and upgraded several existing laboratories for ISMs. India has also introduced new regulations since the year 2000 and several approaches like the introduction of good manufacturing practices have been initiated for traditional systems of medicine. These measures have created high hope for fruitful results. A classical example is that, after such measures were put in place, a US patent was granted to a poly-herbal formulation $\left(\right.$ Artrex $^{\circledR}$ ) for the treatment of arthritis. $^{28}$

Current approaches to promote Ayurvedic medicine are in process. The Indian Government formed the Department of AYUSH, which has accountability and authority related to the production, development, quality assurance, and standardization of ISMs. In 2010, the Department of AYUSH modified several rules to facilitate the licensing and export of Ayurvedic herbal medicines under the categories of Ayurvedic cosmeceuticals, Ayurvedic nutraceuticals, and Ayurvedic extracts. Several other Indian organizations, like the Banaras Hindu University, Gujarat Ayurveda University, National Institute of Ayurveda, Institute of Ayurveda, and
Integrative Medicine, are working on the global promotion of Ayurveda. ${ }^{35}$

India has acknowledged the importance of Ayurveda for providing better primary health care to all people and thus Ayurveda was integrated into the Indian national health care system recently. ${ }^{33}$ This will be a useful measure to provide basic health care facilities to all and to show the effectiveness of Ayurveda. Part two of a status report on Indian medicine and folk healing submitted in February 2013 highlighted the health-seeking activities of consumers, the existing policy of the government on the integration and globalization of Ayurveda, and Unani medicine as adjuvant therapy; the present status of the integration of these medical systems into health care delivery was also reviewed. ${ }^{89}$

In the 21 st century, medical tourism emerged as a key approach to attract people toward herbal medicine and to promote international business. With globalization, people seek better treatment strategies. In several countries, including Japan, the USA, the UK, and European nations, the number of elderly people has increased rapidly. At the same time, life expectancy has also increased progressively, which has resulted in increased demand for natural health care strategies. ${ }^{90,91}$ India has the ability to deliver such strategies. It was estimated that about 1.27 million medical tourists from several countries around the globe, such as the UK, the USA, Canada, China, Bangladesh, and Sri Lanka, visit India with the hope of better, safer traditional herbal medicinal treatment. It has been estimated that foreign-exchange earnings for this are nearly US\$1.8 billion and the market will grow to around US\$3.96 billion by 2015 due to the visits of 2.8 million medical tourists. ${ }^{91}$ This situation clearly indicates the benefit and acceptance of Ayurveda and other Indian medical systems around the world. The potentialities of India are acknowledged by such conditions, which also indicate that there is the opportunity to integrate herbal medicinal systems/formulations into the modern health care system. Medical tourism also presents the opportunity to boost the country's economic conditions and will encourage people toward Indian traditional herbal medicinal systems. ${ }^{91}$

The Materia Medica of India contains 2,000 drugs of natural origin along with their therapeutic utilities, which are derived from traditional systems of medicine. Among these, 400 are from mineral and animal sources, and the rest are from vegetable sources. ${ }^{92}$ The TKDL contains information regarding 500 Ayurveda, 500 Unani, and 200 Siddha formulations and also includes information about 291 plants that are used as ingredients in different traditional formulations. ${ }^{76}$ There are plenty of opportunities to develop 
new products or formulations based on the therapeutic potential of Ayurvedic medicinal plants and getting them accepted as dietary supplements, nutraceuticals, prescription drugs and over-the-counter preparations. ${ }^{24}$ In India a lot of hospitals and private and government-recognized doctors are providing treatment based on Ayurveda and other ISMs. These approaches are showing inspiring results toward the primary health care systems facility and have attracted the attention of people globally.

For centuries, herbal medicine has been acknowledged as having safer drugs and more compatibility with physiological flora. Indian traditional medicine provides the scientific basis and process of utilizing medicinal plants to cure several ailments. In combination with modern science, technologies, and approaches, Indian herbal products/medicinal plants can provide basic and advanced medical care around the world.

\section{Conclusion}

Indian traditional herbal medicine is prevalent around the globe and a large number of people have integrated them along with moden medicine for their different health needs. In spite of their popularity, the rational design, proper standardization, and careful monitoring of Indian traditional herbal formulations and botanicals, along with robust scientific evidence, are essential for their promotion. Approaches are required to promote Indian traditional herbal medicine as modern evidence-based medicine. Thus, the identification of resources and finding of molecular mechanisms are essential, as it could be a resource for new medicine. Current research has shown the potentiality of Indian medicinal plants in drug discovery, though a lot of plants have not been studied and need to be investigated. The careful and scientific integration of herbal medicines from ISMs into the modern system is essential in safeguarding the interests of Indian people and to provide better health care facilities to all.

\section{Disclosure}

The authors declare no conflicts of interest in this work.

\section{References}

1. Ramakrishnappa K. Impact of cultivation and gathering of medicinal plants on biodiversity: Case studies from India. In: Food and Agriculture Organization of the United Nations (FAO). Biodiversity and the Ecosystem Approach in Agriculture, Forestry and Fisheries. Satellite event on the occasion of the Ninth Regular Session of the Commission on Genetic Resources for Food and Agriculture, Rome, Italy, October 12-13, 2002. Rome: FAO; 2002. Available from: http://www.fao.org/ docrep/005/aa021e/AA021e00.htm. Accessed January 9, 2015.

2. Singh $H$. Prospects and challenges for harnessing opportunities in medicinal plants sector in India. Law Environ Develop J. 2007;2(2):196-211.
3. National Biodiversity Authority. Annual Report 2011-2012. Chennai: National Biodiversity Authority; 2012. Available from: http://nbaindia. org/uploaded/pdf/Annual_Report_2011_12_\%20Eng.pdf. Accessed January 9, 2015.

4. Sen S, Chakraborty R, De B. Challenges and opportunities in the advancement of herbal medicine: India's position and role in a global context. J Herb Med. 2011;1(3-4):67-75.

5. Dubey NK, Kumar R, Tripathi P. Global promotion of herbal medicine: India's opportunity. Curr Sci. 2004;86(1):37-41.

6. Sharma A, Shanker C, Tyagi LK, Singh M, Rao ChV. Herbal medicine for market potential in India: an overview. Acad J Plant Sci. 2008;1(2): $26-36$.

7. Government of India Planning Commission. Report of the Task Force on Conservation and Sustainable use of Medicinal Plants. New Delhi: Government of India Planning Commission; 2000. Available from: http://planningcommission.gov.in/aboutus/taskforce/tsk_medi.pdf. Accessed January 9, 2015.

8. Subbarayappa BV. The roots of ancient medicine: an historical outline. J Biosci. 2001;26(2):135-144.

9. Borins M. Traditional medicine in India. Can Fam Physician. 1987;33: 1061-1064.

10. Ministry of Ayurveda, Yoga and Naturopathy, Unani, Siddha and Homoeopathy (AYUSH). About the systems [web page on the Internet]. New Delhi: Ministry of AYUSH; nd [updated September 1, 2010]. Available from: http://indianmedicine.nic.in// index1.asp?lang=1\&linkid=17\&lid=40. Accessed August 20, 2014.

11. Kannaiyan S. Diversity, sustainable use and conservation of medicinal plants. Inaugural address to the International Seminar on Medicinal Plants and Herbal Products, Tirupati, India, March 7-9, 2008. Available from: http://ismphpabstracts.blogspot.in/. Accessed August 20, 2014.

12. Qazi GN. Drug Discovery and Development from Ayurveda. 2006. Available from: http://herbalnet.healthrepository.org/bitstream/ 123456789/2075/3/2.\%20Ayur40-52.pdf. Accessed August 25, 2014.

13. Wakdikar S. Global health care challenge: Indian experiences and new prescriptions. Electron J Biotechnol. 2004;7(3):214-220.

14. Singla RK, Yadav V, Jayalakshmi S. Traditional systems of medicinenow and forever. Webmedcentral. 2012;3(4):WMC003299.

15. Ravishankar B, Shukla VJ. Indian systems of medicine: a brief profile. Afr J Tradit Complement Altern Med. 2007;4(3):319-337.

16. Srinivasan P. National health policy for traditional medicine in India. World Health Forum. 1995;16(2):190-193.

17. Patwardhan B, Vaidya AD, Chorghade M. Ayurveda and natural products drug discovery. Curr Sci. 2004;86(6):789-799.

18. Zysk KG. Siddha Medicine in Tamil Nadu. Tranquebar Initiative Skriftserie No 4. Copenhagen: National Museum's Tranquebar Initiative; 2008. Available from: http://natmus.dk/fileadmin/user_upload/natmus/ forskning/dokumenter/Tranquebar/Skriftserie/Tranquebar_Initiativets_ Skriftserie_nr_04_2008.pdf. Accessed January 12, 2015.

19. Karunamoorthi K, Jegajeevanram K, Xavier J, Vijayalakshmi J, Melita L. Tamil traditional medicinal system - siddha: an indigenous health practice in the international perspectives. International Journal of Genuine Traditional Medicine. 2012;2(2):1-11.

20. Ahmad S. Unani medicine: Introduction and present status in India. Int J Altern Med [serial on the Internet]. 2008;6(1). http://ispub.com/ IJAM/6/1/3747. Accessed September 1, 2014.

21. Unani medicine; Modes of treatment [webpage on the Internet]. Chicago, IL: Encyclopædia Britannica, Inc.; nd [updated July 7, 2014]. Available from: http://www.britannica.com/EBchecked/topic/1899343/Unanimedicine/306595/Modes-of-treatment. Accessed September 1, 2014.

22. Council of Scientific and Industrial Research (CSIR), Ministry of AYUSH. Unani at glance [web page on the Internet]. New Delhi: CSIR and AYUSH; nd. Available from: http://www.tkdl.res.in/tkdl/Langdefault/ Unani/Una_Unani-glance.asp. Accessed August 20, 2014.

23. Devanna N, Chakraborty R, Sen S, De B. Tribal Medicinal Plants of Tripura, India: A Scientific Search. New Delhi: Serial Publications; 2014. 
24. Payyappallimana U. Role of traditional medicine in primary health care: An overview of perspectives and challenges. Yokohama Journal of Social Sciences. 2010;14(6):57-77.

25. Kamboj VP. Herbal medicine. Curr Sci. 2000;78(1):35-39.

26. Bhutani KK, Gohil VM. Natural products drug discovery research in India: status and appraisal. Indian J Exp Biol. 2010;48(3):199-207.

27. Pandey MM, Rastogi S, Rawat AK. Indian traditional Ayurvedic system of medicine and nutritional supplementation. Evid Based Complement Alternat Med. 2013;2013(2013):Article ID 376327.

28. Patwardhan B, Warude D, Pushpangadan P, Bhatt N. Ayurveda and traditional Chinese medicine: a comparative overview. Evid Based Complement Alternat Med. 2005;2(4):465-473.

29. Gurib-Fakim A. Traditional roles and future prospects for medicinal plants in health care. Asian Biotechnology and Development Review. 2011; 13(3):77-83.

30. Traditional Medicine Programme. Regulatory Situation of Herbal Medicines: A Worldwide Review. Geneva: World Health Organization (WHO); 1998. Available from: http://apps.who.int/medicinedocs/pdf/ whozip57e/whozip57e.pdf. Accessed January 12, 2015.

31. Patwardhan B, Mashelkar RA. Traditional medicine-inspired approaches to drug discovery: can Ayurveda show the way forward? Drug Discov Today. 2009; 14(15-16):804-811.

32. Tripathi YB. Molecular approach to Ayurveda. Indian J Exp Biol. 2000;38(5): z409-z414.

33. Sheth PP. Global opportunities and challenges for medicinal uses of Ayurveda, herbal products, neutraceuticals and alternatives. Health Administrator. 2005;19(1):74-75.

34. National Center for Complementary and Integrative Health. Ayurvedic medicine: an introduction [web page on the Internet]. NCCAM Pub No D287. Washington DC: National Center for Complementary and Integrative Health; 2005 [updated November 12, 2013]. Available from: http://nccam.nih.gov/health/ayurveda/introduction.htm. Accessed January $12,2015$.

35. Chaudhary A, Singh N. Contribution of world health organization in the global acceptance of Ayurveda. J Ayurveda Integr Med. 2011;2(4): 179-186.

36. Gaylord S, Norton S, Curtis P, editors. The Convergence of Complementary, Alternative and Conventional Health Care: Educational Resources for Health Professionals. Chapel Hill, NC: University of North Carolina at Chapel Hill Program on Integrative Medicine; 2004.

37. Patel P. Acceptance of Ayurvedic Drugs: The European Challenge and the Indian Perspective. Available from: http://iaf-ngo.org/pdf/ PRAFUL\%20PATEL\%20ARTICLE\%20AT\%20GAU\%20CONFERENCE\%20(No.\%2014).pdf. Accessed September 2, 2014.

38. Gupta I, Gupta V, Parihar A, et al. Effects of Boswellia serrata gum resin in patients with bronchial asthma: results of a double-blind, placebocontrolled, 6-week clinical study. Eur J Med Res. 1998;3(11):511-514.

39. Chopra A, Lavin P, Patwardhan B, Chitre D. Randomized double blind trial of an ayurvedic plant derived formulation for treatment of rheumatoid arthritis. J Rheumatol. 2000;27(6):1365-1372.

40. Gupta R, Singhal S, Goyle A, Sharma VN. Antioxidant and hypocholesterolaemic effects of Terminalia arjuna tree-bark powder: a randomised placebo-controlled trial. JAssoc Physicians India. 2000;49: 231-235.

41. Kumar PU, Adhikari P, Pereira P, Bhat P. Safety and efficacy of Hartone in stable angina pectoris - an open comparative trial. J Assoc Physicians India. 1999;47(7):685-689.

42. Selvadurai S, Shri Vijaya Kirubha T, Senthamari R, Dutta Roy S. Enrichment of modern medicine by Ayurveda. J Pharmacogn Phytochem. 2013;2(3):140-142.

43. Dua P, Dua P. Research in Ayurveda: challenge and way forward. International Journal of Research in Ayurveda and Pharmacy. 2012; 3(1):23-26.

44. Gautam M, Diwanay SS, Gairola S, Shinde YS, Jadhav SS, Patwardhan BK. Immune response modulation to DPT vaccine by aqueous extract of Withania somnifera in experimental system. Int Immunopharmacol. 2004;4(6):841-849.
45. Gautam M, Diwanay S, Gairola S, Shinde Y, Patki P, Patwardhan B. Immunoadjuvant potential of Asparagus racemosus aqueous extract in experimental system. J Ethnopharmacol. 2004;91(2-3):251-255.

46. Arora SK, Narendar S, Srivastava V, Saraf DB, Gupta LK, inventors; Subramaniam $\mathrm{H}$, agent. Herbal composition for treating various disorders including psoriasis, a process for preparation thereof and method for treatment of such disorders. United States patent US 20030194456. July 17, 2003.

47. Singh K, Chandar R, Kapoor NK. Guggulsterone, a potent hypolipidaemic, prevents oxidation of low density lipoprotein. Phytother Res. 1998;11(4):291-294.

48. Pal SK, Shukla Y. Herbal medicine: current status and the future. Asian Pac J Cancer Prev. 2003;4(4):281-288.

49. United Nations Office for South-South Cooperation, Third World Network of Scientific Organizations, Third World Academy of Sciences. Drug discovery and development: India. In: Examples of the Development of Pharmaceutical Products from Medicinal Plants. Vol 10, Sharing Innovative Experiences. New York, NY: United Nations Office for South-South Cooperation; 2005:29-44. Available from: http:// tcdc2.undp.org/GSSDAcademy/SIE/Download.aspx?V=10\&C=23. Accessed January 12, 2015.

50. Mukherjee PK, Rai S, Bhattacharyya S, et al. Clinical study of 'Triphala'a well known phytomedicine from India. Iranian Journal of Pharmacology and Therapeutics. 2006;5(1):51-54.

51. Balganesh T, Kundu TK, Chakraborty TK, Roy S. Drug discovery research in India: current state and future prospects. ACS Med Chem Lett. 2014;5(7):724-726.

52. Mishra B, Mohapatra A, Krushna B. Clinical Trial Done for Tarika 100\% Herbal Pimple Remover. Available from: ayurlabsindia.com/ tarika_clinical_trial.pdf. Accessed August 24, 2014.

53. Shukla DN, Chandola HM, Ravishankar B. Psychosomatic health disturbance in premature ageing and its treatment with Guduchyadi ghrita rasayana. Journal of Research in Ayurveda and Siddha. 2008;29(1):1-13.

54. Sathye SM. Clinical study of Amalki Rasayana in patients suffering from age related macular degeneration (ARMD). Journal of Research in Ayurveda and Siddha. 2008;29(1):27-37.

55. Subramoniam A. Present scenario, challenges and future perspectives in plant based medicine development. Annals of Phytomedicine. 2014; 3(1):31-36.

56. Pholtan Rajeev SR, Sewwandi UD. A clinical research of Siddha drug "GLY CYN NEU" ointment for azhalvaatham (Neuropathy). Int J Sci Res. 2013;2(8):29-33.

57. Velpandian V, Pitchiah Kumar MP, Anbu N, Musthafa Md, Kanakavalli K Clinical evaluation of siddha drug Gowri Chinthamani Chendooram in the management of osteoarthritis. Int J Pharma Sci Inv. 2013;2(1):26-32.

58. Muthukumar B. Study on efficacy of Siddha drugs (CL and CEN) in rheumatoid arthritis. Indian Journal of Traditional Knowledge. 2009;8(3):446-448.

59. Reddi PM. A touch of turmeric: examining an Ayurvedic treasure. Advances in Anthropology. 2013;3(2):91-95.

60. Aggarwal BB, Sundaram C, Malani N, Ichikawa H. Curcumin: the Indian solid gold. Adv Exp Med Biol. 2007;595:1-75.

61. Dey A, De JN. Rauvolfia serpentine (L.) Benth. Ex Kurz. - a review. Asian J Plant Sci. 2010;9(6):285-298.

62. Kumari R, Rathi B, Rani A, Bhatnagar S. Rauvolfia serpentina L. Benth ex Kurz.: phytochemical, pharmacological and therapeutic aspects. Int J Pharm Sci Rev Res. 2013;23(2):348-355.

63. López-Muñoz F, Bhatara VS, Alamo C, Cuenca E. [Historical approach to reserpine discovery and its introduction in psychiatry.] Actas Esp Psiquiatr. 2004;32(6):387-395. Spanish.

64. Shikha S, Nidhi M, Upama M. Bacopa monniera - a future perspective. Int J Pharma Sci Drug Res. 2009;1:154-157.

65. Jachak SM, Saklani A. Challenges and opportunities in drug discovery from plants. Curr Sci. 2007;92(9):1251-1257.

66. Morgan M. Coleus forskohlii Root: The Benefits of Forskolin. MediHerb; 2006. Available from: http://www.mediherb.com.au/articles/6092.pdf. 
67. Kumara PM, Soujanya KN, Ravikanth G, Vasudeva R, Ganeshaiah KN, Shaanker RU. Rohitukine, a chromone alkaloid and a precursor of flavopiridol, is produced by endophytic fungi isolated from Dysoxylum binectariferum Hook.f and Amoora rohituka (Roxb). Wight and Arn. Phytomedicine. 2014;21(4):541-546.

68. Blagosklonny MV. Flavopiridol, an inhibitor of transcription: implications, problems and solutions. Cell Cycle. 2004;3(12): $1537-1542$.

69. Sumangala RC, Mohana Kumara P, Shaanker RU, Vasudeva R, Ravikanth G. Development and characterization of microsatellite markers for Dysoxylum binectariferum, a medicinally important tree species in Western Ghats, India. J Genet. 2013;92(3):e85-e88.

70. Chakraborty PS, Singh JP, Rai MK, et al. Amoora rohituka: a multicentric clinical verification study conducted by CCRH. Indian Journal of Research in Homoeopathy. 2008;2(1):19-25.

71. Raju J, Rao CV. Diosgenin, a steroid saponin constituent of Yams and Fenugreek: emerging evidence for applications in medicine. In: Rasooli I, editor. Bioactive Compounds in Phytomedicine. Rijeka: InTech; 2012:126-142.

72. Aggarwal BB, Prasad S, Reuter S, et al. Identification of novel antiinflammatory agents from Ayurvedic medicine for prevention of chronic diseases: "reverse pharmacology" and "bedside to bench" approach. Curr Drug Targets. 2011;12(11):1595-1653.

73. Joy PP, Thomas J, Mathew S, Skaria BP. Medicinal Plants. Ernakulam: Kerala Agricultural University; 1998. Available from: http://www. armchairpatriot.com/HardCorePrepper/Medicinal\%20Plants.pdf. Accessed February 3, 2015.

74. Aggarwal BB, Ichikawa H, Garodia P, et al. From traditional Ayurvedic medicine to modern medicine: identification of therapeutic targets for suppression of inflammation and cancer. Expert Opin Ther Targets. 2006;10(1):87-118.

75. Safayhi H, Mack T, Sabieraj J, Anazodo MI, Subramanian LR, Ammon HP. Boswellic acids: novel, specific, nonredox inhibitors of 5-lipoxygenase. J Pharmacol Exp Ther. 1992;261(3):1143-1146.

76. Sen S, Chakraborty R. Traditional Knowledge Digital Library: a distinctive approach to protect and promote Indian indigenous medicinal treasure. Curr Sci. 2014;106(10):1340-1343.

77. Rana KK, Rana S. Review on present status and future of herbal medicine. Beats of Natural Sciences. 2014;1(2):1-8.

78. Dias DA, Urban S, Roessner U. A historical overview of natural products in drug discovery. Metabolites. 2012;2(2):303-336.

79. Rivera JO, Loya AM, Ceballos R. Use of herbal medicines and implications for conventional drug therapy medical sciences. Altern Integr Med. 2013;2:1-6.
80. Sahoo N, Manchikanti P. Herbal drug regulation and commercialization: an Indian industry perspective. J Alternat Complement Med. 2013; 19(12):957-963.

81. Patwardhan B. European Union ban on Ayurvedic medicines. J Ayurveda Integr Med. 2011;2(2):47-48.

82. Kessler C, Wischnewsky M, Michalsen A, Eisenmann C, Melzer J. Ayurveda: between religion, spirituality, and medicine. Evid Based Complement Alternat Med. 2013;2013:952432.

83. Marichamy K, Kumar NY, Ganesan A. Sustainable development in exports of herbals and Ayurveda, Siddha, Unani and homoeopathy (AYUSH) in India. Science Park Research Journal. 2014;1(27):1-6.

84. SME Times News Bureau. Indian herbal industry to double by 2015 : study. SME Times [online]. 2010 March 6. Available from: http://www. smetimes.in/smetimes/news/top-stories/2010/Mar/06/indian-herbalindustry-to-double-by-2015-study14569.html. Accessed September 28, 2014

85. Kumar MR, Janagam D. Export and import pattern of medicinal plants in India. Indian J Sci Technol. 2011;4(3):245-248.

86. Agarwal P, Alok S, Fatima A, Verma A. Current scenario of herbal technology world wide: An overview. International Journal of Pharmaceutical Sciences and Research. 2013;4(11):4105-4117.

87. Cheng YC. Why and how to globalize traditional Chinese medicine. $J$ Tradit Complement Med. 2011;1(1):1-4.

88. WHO. The Promotion and Development of Traditional Medicine: Report of a WHO Meeting. WHO Technical Report Series 622. Geneva: WHO; 1978. Available from: http://apps.who.int/medicinedocs/documents/ s7147e/s7147e.pdf. Accessed January 12, 2015.

89. Status of Indian medicine and folk healing: With a focus on integration of AYUSH medical systems in healthcare delivery. Ayu. 2012;33(4): 461-465.

90. Lee C. Medical tourism, an innovative opportunity for entrepreneurs. Journal of Asia Entrepreneurship and Sustainability. 2007;3(1).

91. Shanmugam KR. Medical Tourism in India: Progress, Opportunities and Challenges. Monograph 26/2013. Chennai: Madras School of Economics; 2013. Available from: http://www.mse.ac.in/pub/Monograph\%2026. pdf. Accessed January 12, 2015.

92. Mukherjee PK, Venkatesh M, Kumar V. An overview on the development in regulation and control of medicinal and aromatic plants in the Indian system of medicine. Boletín Latinoamericano y del Caribe de Plantas Medicinales y Aromáticas. 2007;6(4):129-136.
Botanics: Targets and Therapy

\section{Publish your work in this journal}

Botanics: Targets and Therapy is an international, peer-reviewed, open access journal focusing on the discovery and development of active compounds based upon or found naturally occurring in the plant kingdom that may have therapeutic potential in any disease state. The manuscript management system is completely online and includes a very

\section{Dovepress}

quick and fair peer-review system. Visit http://www.dovepress.com/ testimonials.php to read real quotes from published authors. 